\title{
Knowledge sharing and individual performance: The case of Vietnam
}

\author{
Thi Phuong Linh Nguyen ${ }^{a}$, Xuan Hau Doan ${ }^{a}$, Manh Dung Tran ${ }^{a^{*}}$, Trung Thanh Le ${ }^{a}$ and Quynh \\ Trang Nguyen ${ }^{b}$
}

${ }^{a}$ National Economics University, Vietnam

${ }^{b}$ Banking Academy, Vietnam

\begin{tabular}{l}
\hline C H R O N I C L E \\
\hline Article history: \\
Received October 5, 2018 \\
Accepted November 282018 \\
Available online \\
November 282018 \\
\hline Keywords: \\
Knowledge sharing \\
Knowledge donation \\
Knowledge collection \\
Individual performance
\end{tabular}

\section{A B S T R A C T}

\begin{abstract}
Knowledge sharing plays an important role in management of universities. Vietnam universities are not highly regarded for their teaching quality and scientific research. It is therefore necessary to promote knowledge sharing through two central processes: knowledge donation and collection as well as individual performance of lecturers. Based on a sample size survey of 312 university lecturers in Vietnam and the methods of analyzing exploration factor (EFA), factor analysis (CFA), structural equation modeling (SEM) to examine the hypotheses of the survey, the study determines that two individual factors; namely job satisfaction and other involvement significantly influenced knowledge donation process. One individual factor also positively influences knowledge collection process, knowledge self-efficacy, and lecturers' willingness to donate knowledge to improve individual performance. Finally, several suggestions for enhancing the knowledge sharing and individual performance of lecturers for university managers are given.
\end{abstract}

(C) 2019 by the authors; licensee Growing Science, Canada

\section{Introduction}

The university, as a center for knowledge creation and cultural preservation, not only develops human resources but also maintains, manages and develops new knowledge that meets the needs of society. Knowledge is considered to be an invaluable asset, a major source of national development and knowledge management (Anantatmula, 2007) and therefore inevitably becomes an issue that needs to be addressed in order to achieve the goals of organizations, particularly knowledge creation centers like universities. Many management processes in universities have considered knowledge management, such as management of training activities, management of science-technology activities, personnel management, training and updating new knowledge for lecturers, creation of e-governance system, knowledge sharing among lecturers, etc. The knowledge gained by lecturers and researchers is regularly published in scholarly journals, books but knowledge is often scattered without the necessary association and interrelationships. This is the task of the knowledge management team to establish links, correlations and knowledge management systematically. However, grasping the tacit knowledge of not only the teachers and researchers, but also of other employees and students, poses a challenge to the universities.

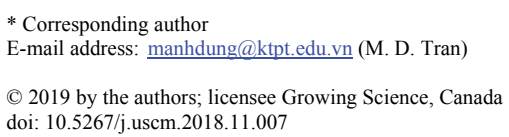


Modern universities are complex organizations, with departments, faculties, laboratories, and research laboratories. When a lecturer, administrator or librarian is retired, a gap is created. Those who are replaced in their positions are often compared with their predecessors, and in many cases, the results are inappropriate. Although, knowledge arises through long-term efforts of learning and research over a long period of time, and therefore it cannot automatically be transferred to others quickly; but when experience and knowledge are shared with others, and this sharing takes place in a context appropriate to the rules, procedures, and technology that support it, we can say that shared knowledge have appeared. Knowledge sharing is really important with universities in general and faculties in particular. Mikulecky and Mikulecka (1999) argue that because of its nature, the university environment is appropriate for the application of knowledge management principles and methods, as universities often have a modern information infrastructure, sharing knowledge with others is the natural law of the teacher. McAndrew et al. (2004) in their study confirm that lecturers wish to know what their colleagues are thinking, what approaches they are currently using, opportunities to discuss them, and the ideas with colleagues across the university. In addition, knowledge sharing is closely related to individual performance and competitiveness (Du et al., 2007). Akram and Bokhari (2011) argue that effective knowledge sharing is essential for determining the impact on individual performance. Research that shows the relationships between knowledge sharing and individual performance is limited so this is a space for researchers to learn about this relationship (Du et al., 2007). In the field of education, the study of knowledge sharing and individual performance of university lecturers is also essential to increase competitiveness in the knowledge economy in the context of globalization.

To fill this gap, this study develops a research model that links knowledge sharing enablers, processes and individual performance. The study examines the influence of individual factors (enjoyment in helping others, knowledge self-efficacy, job involvement), organizational factors (management support and organizational rewards) and technology factors (information and communication technology) on knowledge sharing processes and whether leads to individual performance. Based on a survey of 312 lecturers from 30 universities in Vietnam, this study applies the structural equation modeling (SEM) to investigate the research model. Additionally, the current study contributes to knowledge sharing research by further clarifying which factors are essential for knowledge sharing effectively. At a minimum, the findings of this study provide a theoretical basis, and simultaneously can be used to analyze relationships among knowledge sharing enablers, processes, and individual performance. From a managerial perspective, the findings of this study can improve understanding and practice of organizational management of knowledge sharing and individual performance. Specifically, this study identifies several factors essential to successful knowledge sharing and discusses the implications of these factors for developing organizational strategies that encourage and foster knowledge sharing.

\section{Research Model and Hypotheses}

The separation of knowledge sharing into two different processes, inherited by Van den Hooff and de Ridder (2004) and Van den Hooff et al. (2004) from three previous studies. Weggeman (2000) studied the difference between contributors and recipients in knowledge sharing process, Oldenkamp (2001) discussed how to share knowledge between the people who wish to share the knowledge and the people who wish to learn the knowledge. Ardichvili et al. (2003) viewed the knowledge sharing as the provision of new knowledge and the demand for the new knowledge. Hooff and Weenen (2004) pointed out that the two processes of knowledge donation and collection are different, and can be hoped to be impacted by different factors. The factors that may affect these two processes are described in details as follows:

\section{Enjoyment in helping others}

Enjoyment in helping others is rooted in the concept of altruism, in contrast to selfishness, that is, belief in unprejudiced and disinterested acts (Lin, 2007). Osterloh and Frey (2000) argued that knowledge sharing is motivated by intrinsic motivations. Wasko and Faraj (2000) also demonstrated that individuals are motivated because they like to help others. Staff with altruism will have motivation and 
interest in helping people (Davenport \& Prusak, 1998). Altruism can promote an individual's knowledge sharing with others without receiving any benefits (Al-Qadhi et al., 2015). The following hypothesis thus is proposed:

$\mathrm{H}_{1}$. Enjoyment in helping others positively influences lecturer willingness to both (a) donate and (b) collect knowledge.

\section{Knowledge self-efficacy}

Chiu et al. (2006) said that the desire to share knowledge is not enough to do knowledge sharing and that a knowledge owner must be able to perceive it to be accomplished. When people think their expertise can improve productivity and increase productivity, their attitude to knowledge sharing will change and as a result, they will be more inclined to share knowledge with others (Shin et al., 2007). Knowledge self-efficacy can encourage employees to share knowledge with others (Wasko \& Faraj, 2005). Many researchers have shown that the more confident employees are with their own knowledge, the more willing they are to share knowledge in order to fulfill specific responsibilities (Constant et al., 1994). Hence, the following hypothesis is proposed:

$\mathrm{H}_{2}$. Knowledge self-efficacy positively influences lecturer willingness to both (a) donate and (b) collect knowledge.

\section{Job involvement}

Job involvement is the extent to which a person feels the importance of work to himself (Lodahl \& Kejner, 1965). Job involvement helps employees feel confident in sharing their work-related knowledge with colleagues (Teh \& Sun, 2012). Hence, the following hypothesis is proposed:

$\mathrm{H}_{3}$. Job involvement influences lecturer willingness to both (a) donate and (b) collect knowledge.

\section{Management support}

Managerial support is seen as an important factor influencing knowledge sharing among employees (Lee et al., 2006). Islam et al. (2014) emphasized the role of managerial support for knowledge sharing, leadership, contributing to employee learning from personal experience, persuading employees transfer knowledge to form new knowledge and influencing decision-making on the basis of valuable knowledge shared among employees. Managerial support influences both the level and quality of knowledge sharing by influencing employee engagement in knowledge management (Lee et al., 2006). The following hypothesis is therefore formulated:

$\mathrm{H}_{4}$. Top management support positively influences lecturer willingness to both (a) donate and (b) collect knowledge.

\section{Rewards}

Hansen and Avital (2005) argued that the main factors shaping an employee's view of knowledge sharing are rewards. Chaudhry (2005) concluded that rewards are inspirational elements for knowledge sharing. Individuals working in an organization are expected to be recognized and rewarded for sharing their knowledge, experience, expertise with others. Rewards include recognition and reward as a tool to facilitate knowledge sharing and help build a supportive culture (Liebowitz \& Megbolugbe, 2003). The following hypothesis is proposed:

$\mathrm{H}_{5}$. Rewards positively influence lecturer willingness to both (a) donate and (b) collect knowledge.

\section{Information and communication technology (ICT)}

Information technology is also seen as an indispensable tool to support the discovery of useful knowledge (Ho et al., 2012). Collaborative tools such as the intranet system allow people to work together and collaborate interactively. Individual knowledge, therefore, is transformed into 
organizational knowledge through the support of information technology (Zhao \& Luo, 2005). According to Teece (1998), the ability of information and communication technologies is to reduce barriers to knowledge sharing. It is important to identify relevant knowledge in different parts of an organization to build a technical infrastructure to support and disseminate knowledge (Zakaria et al., 2004). Hence, the following hypothesis is proposed:

$\mathrm{H}_{6}$. ICT support positively influences lecturer willingness to both (a) donate and (b) collect knowledge.

Individual performance is the behavior shown or something made by the staffs (Campbell, 1990). According Motowildo et al. (1997), individual performance can be assessed according to the extent to which it contributes to the efficiency of the organization. Onukwube et al. (2010) considered that it is the behavior and result that the employees are involved in or carry on to contribute to the organization's objectives. Individual performance relates to the degree to which an employee has the ability to perform assigned tasks or how the work is completed contributes to the implementation of organizational goals (Mawoli \& Babandako, 2011). Von Krogh et al. (2000) pointed out that effective knowledge sharing leads to better business processes, enhances organizational creativity, performance and value of products and services. Du et al. (2007) also concluded that knowledge sharing have positive effects on individual performance. The following hypothesis is proposed:

$\mathrm{H}_{7}$. Knowledge donation (a) and collection (b) positively influence to individual performance of lecturer

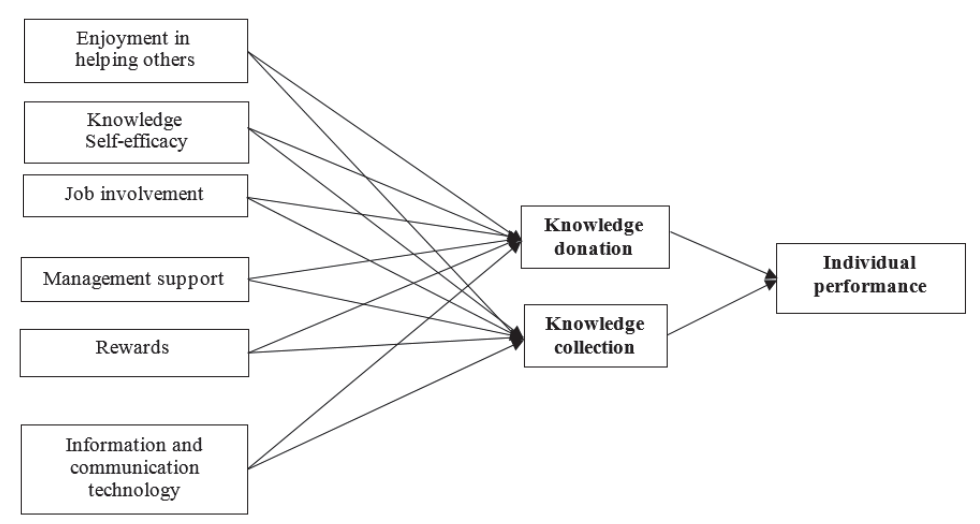

\section{Research Methodology}

Fig. 1. Research Model

\section{Data collection}

We conducted in-depth interviews with 10 lecturers of Vietnam universities in the city of Hanoi to evaluate and adjust the questionnaire, and clarify the perceptions regarding the three processes of knowledge sharing. The questions in the in-depth interview focused on the following issues: knowledge sharing conditions, knowledge sharing content, factors affecting the process of knowledge donation, factors affecting the process of knowledge collection and the relationship among knowledge donation, collection and individual performance. The contents of the interview were recorded, stored and encrypted in the computer. The recording was then tape-taped, synthesized and analyzed to make conclusions to understand the similarities and differences between theoretical and practical models at Vietnamese universities. From the results of in-depth interviews, we identified the formal model for the study. A quantitative preliminary study with 25 lecturers was conducted to complete the questionnaire, to avoid errors and mislead the meaning of the observations, and to verify the reliability of the scales before conducting a formal investigation. Formal questionnaire survey was used to collect data from lecturers of Vietnam universities in a convenient way. We investigated through questionnaires sent directly and via the Internet (email, social networks and forums) thanks to google docs tool. Time to collect data was from June to August, 2017. The results were 180 direct and 152 online questionnaires. After screening the invalid questionnaires due to lack of information and 
unreliability, we collected 312 valid questionnaires to use for analysis. The demographic characteristics of the sample are presented in Table 1 . The gender of the respondents: $38.5 \%$ questionnaire was answered by men; $61.5 \%$ of questionnaire was answered by women. Regarding the age of the respondents: $23.7 \%$ respondents aged $20-30$ years old; $51.3 \%$ respondents aged $31-40$ years old; $16.0 \%$ respondents aged $41-50$ years old; $5.8 \%$ respondents aged $51-60$ years old; $23.7 \%$ of subjects remaining respondents aged over 60 years old. Regarding educational qualification of respondents: $4.5 \%$ of respondents had bachelor's degree; $63.5 \%$ of respondents maintained master's degree; $30.1 \%$ of respondents claimed to have doctor's degree; the remaining $1.9 \%$ of respondents had post-doctoral degree. On the work experience of the respondents: $3.8 \%$ of respondents had work experience under 1 year; $21.8 \%$ of respondents from $1-5$ years; $29.5 \%$ of respondents from $6-10$ years; $22.4 \%$ of respondents from 11-15 years and the remaining $22.4 \%$ of respondents had work experiences of over 15 years.

\section{Table 1}

Characteristics of the sample

\begin{tabular}{|c|c|c|}
\hline Category & Number of respondents & Percentages $(\%)$ \\
\hline \multicolumn{3}{|l|}{ Sex } \\
\hline Male & 120 & 38.5 \\
\hline Female & 192 & 61.5 \\
\hline \multicolumn{3}{|l|}{ Age } \\
\hline From 20 to 30 & 74 & 23.7 \\
\hline From 31 to 40 & 160 & 51.3 \\
\hline From 41 to 50 & 50 & 16.0 \\
\hline From 51 to 60 & 18 & 5.8 \\
\hline Over 60 & 74 & 23.7 \\
\hline \multicolumn{3}{|c|}{ Education qualification } \\
\hline Bachelor & 14 & 4.5 \\
\hline Master & 198 & 63.5 \\
\hline Doctor & 94 & 30.1 \\
\hline Post-Doctoral & 6 & 1.9 \\
\hline \multicolumn{3}{|l|}{ Working experience } \\
\hline Under 1 year & 12 & 3.8 \\
\hline From 1 to 5 years & 68 & 21.8 \\
\hline From 6 to 10 years & 92 & 29.5 \\
\hline From 11 to 15 years & 70 & 22.4 \\
\hline Over 15 years & 70 & 22.4 \\
\hline
\end{tabular}

\section{Measures}

Scales were drawn from literature review and in-depth interviews. Observations and scales were used from foreign studies, which were translated from English into Vietnamese and then translated back into Vietnamese. After completing the translation, we have consulted with some experts to ensure that the variables and scales were accurately and clearly translated and did not significantly change the meaning. All constructs were measured using multiple items. All items were measured using a fivepoint Likert-type scale (ranging from $1=$ strongly disagree to $5=$ strongly agree). A list of items for each scale is presented in the appendix. The measurement approach for each theoretical construct in the model is described briefly below. Enjoyment in helping others was measured using four items derived from Wasko and Faraj (2000), which focused on belief in the act of carefree and unprofessional interest in the interests of others. A five-item scale measuring knowledge self-efficacy was adapted from a measure developed by Bock et al. (2005). It shows the action of the individual recognizes his or her ability to provide detailed information about how the individual makes the decision to share the knowledge. Job involvement was described by five items adapted form studies by Kanungo (1982). Management support was measured using five items adapted from studies by Lu et al. (2006). These measurements assess the vision of the organization is related to leadership involvement in the effective use of knowledge. Rewards were measured using four items derived from Kankanhalli et al. (2005) which were defined as financial and non-financial rewards provided to knowledge-sharing people. Additionally, information and communication technology was measured based on three items taken from Lee and Choi (2003), which referred to the degree of technological usability and capability regarding knowledge sharing. Knowledge donating was measured using four items adapted from an 
investigation by Hsiu-Fen Lin (2007) which assess the degree of employee willingness to contribute knowledge to colleagues. Knowledge collecting was measured using four items derived from Hsiu-Fen Lin (2007), which referred to consult with colleagues to share their own knowledge. Finally, individual performance was measured using nine items derived from Bontis and Serenko (2007) and Anantatmula (2007). These items describe the quality of work, punctuality, results, performance of university lecturers.

\section{Research Results}

The reliability test is used to confirm whether the determine measures can be employed as representation of the global independent and its sub - variables and global depend variable and its sub - variable. Previous studies have shown that observers with a small (less than 0.3) variable-toaggregation coefficient will be excluded and criteria for scale selection when Cronbach's Alpha reliability is greater than 0.6. The larger the Cronbach's Alpha, the higher the internal consistency (Nunnally \& Bernstein, 1994). Taken together, nine variables in the survey had Cronbach's Alpha ranged from 0.707 to 0.907 . All of these values are above 0.6 , generally considered to be the higher limit of reliability (Hair et al., 1995). The appendix presents Cronbach's Alpha of indicators in the measurement model.

\section{Table 1}

KMO and Bartlett's Test

\begin{tabular}{llr}
\hline Kaiser-Meyer-Olkin Measure of Sampling Adequacy. & & .817 \\
\hline Bartlett's Test of Sphericity & Approx. Chi-Square & 8038.392 \\
& df & 903 \\
& Sig. & .000 \\
\hline
\end{tabular}

To confirm that this study data set is correct for factor analysis, the researchers assessed whether the Kaiser-Meyer-Olkin (KMO) measure of sampling adequacy value was 0.6 or above and determined that the Barlett's test of Sphericity value was significant (i.e.: 0.5 or less). As a result, all coefficients are relevant and significant in this study when $\mathrm{KMO}>0.6$ and sig. $=0$. To define how many factors to retain, a number of issues were considered.

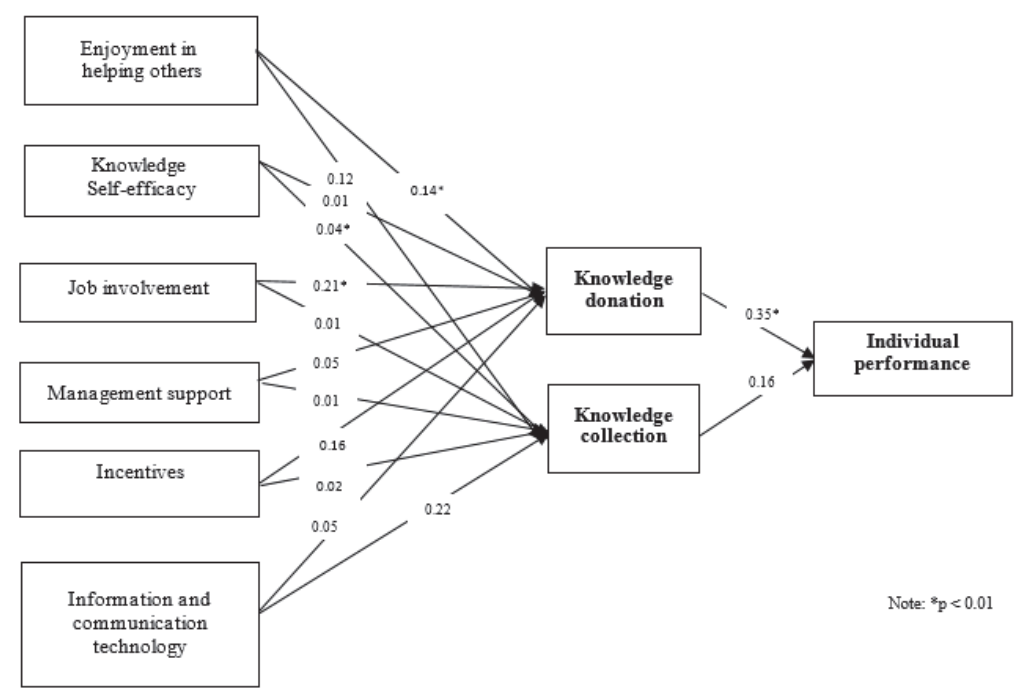

Fig. 2. Results of SEM theoretical model (standardized)

Using Kaiser's criterion, factors with an eigenvalue greater than one are suitable. In this phase, all nine components recorded eigenvalues above 1. These nine components explain 66.755 percent of variance. Subsequently, all observations were included in the EFA analysis. Four items were deleted based on their strength of loading or cross loading: Se1, Se2, In1 and In3. Pe5 was separated from the scales in 
the study. This observation relates to initiatives, which differ from the other observations. Specific analysis results are described in the appendix. In verifying the scale, the CFA method in linear modeling (SEM) analysis has many advantages over conventional methods such as the coefficient-matching method, exploratory factor analysis (EFA). This method is characterized by allowing us to examine the theoretical structure of the scales as well as the relationship between a research concept and other concepts without deviation from the measurement error (Steenkamp \& van Trijp, 1991). Adequacy of the model is reflected in Chi-square (CMIN); Chi-square adjusted by degrees of freedom (CMIN/df); Comparative Fit Index - CFI; Tucker \& Lewis Index - TLI; Root Mean Square Error Approximation RMSEA. The model is considered appropriate when the GFI, TLI, CFI values are $\geq 0.9$ (Bentler \& Bonnet, 1980); CMIN / df $\leq 2$; RMSEA $\leq 0.08$ (Steiger, 1990). Nguyen et al. (2008) suggested that the model received TLI, CFI $\geq 0.9$, CMIN / df $\leq 2$, RMSEA $\leq 0.08$, thus the model was considered appropriate for the data. We conducted factor analysis confirmed (CFA) to test the suitability of the model scale with the data collected. Results obtained in Fig 2: Chi-square/df =1,393; GFI =0,774; TLI $=0,906 ; \mathrm{CFI}=0,915$ and RMSEA $=0,050$ (standardized estimate), showing scale models suitable for research data. Table 3 shows the results of testing hypotheses with path coefficient derived from structural equation modeling (SEM). The hypothesis is accepted as $\mathrm{H}_{1 \mathrm{a}}, \mathrm{H}_{2 \mathrm{~b}}, \mathrm{H}_{3 \mathrm{a}}$ and $\mathrm{H}_{7 \mathrm{a}}$.

\section{Table 3}

\section{Results of Hypothesis Testing}

\begin{tabular}{|c|c|c|c|}
\hline Hypotheses & Hypothesized path & Path coefficient & Results \\
\hline H1a & Enjoyment in helping others $\rightarrow$ knowledge donation & $0.14^{*}$ & Supported \\
\hline $\mathrm{H} 1 \mathrm{~b}$ & Enjoyment in helping others $\rightarrow$ knowledge collection & 0.12 & Not Supported \\
\hline $\mathrm{H} 2 \mathrm{a}$ & Knowledge self-efficacy $\rightarrow$ knowledge donation & 0.01 & Not Supported \\
\hline $\mathrm{H} 2 \mathrm{~b}$ & Knowledge self-efficacy $\rightarrow$ knowledge collection & $0.04 *$ & Supported \\
\hline $\mathrm{H} 3 \mathrm{a}$ & Job involvement $\rightarrow$ knowledge donation & $0.21 *$ & Supported \\
\hline $\mathrm{H} 3 \mathrm{~b}$ & Job involvement $\rightarrow$ knowledge collection & 0.01 & Not Supported \\
\hline $\mathrm{H} 4 \mathrm{a}$ & Management support $\rightarrow$ knowledge donation & 0.05 & Not Supported \\
\hline $\mathrm{H} 4 \mathrm{~b}$ & Management support $\rightarrow$ knowledge collection & 0.01 & Not Supported \\
\hline H5a & Rewards $\rightarrow$ knowledge donation & 0.16 & Not Supported \\
\hline $\mathrm{H} 5 \mathrm{~b}$ & Rewards $\rightarrow$ knowledge collection & 0.02 & Not Supported \\
\hline H6а & Information and communication technology $\rightarrow$ knowledge donation & 0.05 & Not Supported \\
\hline H6b & Information and communication technology $\rightarrow$ knowledge collection & 0.22 & Not Supported \\
\hline $\mathrm{H} 7 \mathrm{a}$ & Knowledge donation $\rightarrow$ individual performance & $0.35^{*}$ & Supported \\
\hline $\mathrm{H} 7 \mathrm{~b}$ & Knowledge collection $\rightarrow$ individual performance & 0.16 & Not Supported \\
\hline
\end{tabular}

\section{Discussion and Implications}

This research approached both theoretical and practical perspectives. Theoretically, this research showed a research model for empirical studies to explore factors affecting two knowledge sharing processes and the relationship between two knowledge sharing processes and individual performance. The results from a structural equation modeling (SEM) approach give significant supports for some hypothesized relations. The results show that two individual factors; namely enjoyment in helping others and job involvement significantly influence knowledge donation process and one individual factor positively influences knowledge collection process (knowledge self-efficacy). The results also indicate that lecturers willingness to donate knowledge enable themselves to improve individual performance. From a practical perspective, some suggestions may be provided about how universities can promote knowledge sharing process to improve lecturers' performance. Discussion of the findings, implications for managers are described below.

\subsection{Discuss research findings}

The main purpose of this study was to determine the relationship between factors related to knowledge sharing processes and between knowledge sharing processes and individual performance. After testing the hypotheses, some conclusions are as follows:

(i) Enjoyment in helping others is positively correlated with knowledge donation. The result is consistent with several previous studies (e.g. Lin, 2007). The result indicates that lecturers who feel 
satisfied in donating knowledge and helping others tend to be more motivated to share knowledge with colleagues. Meaning that when lecturers feel comfortable about donating knowledge, they tend to be more positively to carry out the sharing behavior.

(ii) Knowledge self-efficacy is positively correlated with knowledge collection. The result is consistent with several previous studies (e.g. Lin, 2007). Additionally, a sense of the competence and confidence of lecturers may be requirement for employees to engage in knowledge sharing. That is, lecturers who believe in their abilities to share organizationally essential knowledge tend to have stronger momentum to share knowledge with their colleagues and collect knowledge from colleagues.

(iii) Job involvement has a positive influence to knowledge donation process. The result are consistent with Teh and Sun (2012) and some answers from interviewees.

"I am willing to donate the knowledge I have for my colleagues because of the nature of research and teaching at the university. I have been working here since graduation from the university, so far for over 15 years, it has been part of my life to share my knowledge with my colleagues".

"I have been teaching for many years. I spend significant amount of time in my work. University lecturers to successfully complete the teaching must always update new knowledge from the surrounding, which may come from colleagues. My attachment to teaching has given me the impetus for imparting knowledge to young lectures so that they can find their way in their careers".

(iv) Knowledge donation is positively correlated with individual performance. This result is also shown in the study by Von Krogh et al. (2000), Akram and Bokhari (2011), Muhammad et al. (2011), Tran et al. (2013), Kuzu and Ozilhan (2014). In addition, this result is confirmed by the answers of some lecturers participating in in-depth interviews:

"When I share my knowledge and get support from colleagues, I feel my understanding is improving and the results of my work are better than expected".

"My knowledge after the exchanging with colleagues may clarify many issues. That helps me do a good job teaching and researching science. We often participate in seminars or scientific activities to jointly issue, exchange and solve the ultimate problem".

(v) Other hypotheses discarded on the relationship between some factors and two knowledge sharing processes as well as between knowledge collection and individual performance. These are the results not expected to happen before performing quantitative research.

\subsection{Implications for managers}

The study has proposed the following implications for helping managers establish a perfectly knowledge sharing strategy:

Firstly, the findings of this study show that individual factors are associated with two knowledge sharing processes. Because enjoyment in helping others significantly influenced knowledge donation, managers need to focus to increase the level of enjoyment. Impact on perception through stories, real situations can be a way to increase the excitement of lecturers when sharing knowledge with colleagues. Managers care about developing and maintaining knowledge sharing should try enhancing the positive mood state of lecturers (i.e. enjoyment in helping others). Managers can also create open spaces and share them among individuals at the university. Today's local universities often do not have a private sector or reading room for lecturers, while this is a channel for faculty members to exchange knowledge to each other.

Secondly, managers should pay more attention to provide significant feedback to improve lecturers' knowledge self-efficacy. For instance, weekly/monthly/yearly review reports should include the contribution of some lecturers to the work of other lecturers through knowledge sharing. These stories 
help lecturers increase awareness of the meaning of knowledge sharing as well as enhance the role of each individual with the results of other individual work and the results of the organization's work.

Thirdly, each lecturer should be aware of the significance of teaching and scientific research to the training and development of each individual. Managers should spend time chatting, communicating with lecturers to listen to their aspirations and concerns regarding work. In the seminars, managers will understand the degree of attachment to the work of the lecturers and how they can be more engaged with their works, thereby enhancing knowledge sharing.

Finally, managers hope lecturers perform good teaching and research work. Therefore, one of the ways to increase the performance of the lecturers' work is to promote the act of donating knowledge. Each Vietnam universities' pedagogical environment, also known as the academic environment, knowledge donation process is necessary and should be encouraged.

\section{References}

Akram, F., \& Bokhari, R. (2011). The role of knowledge sharing on individual performance, considering the factor of motivation-the conceptual framework. International Journal of Multidisciplinary Sciences and Engineering, 2(9), 44-48.

Al-Qadhi, Y. H., Md Nor, K., Ologbo, A. C., \& Knight, M. B. (2015). Knowledge sharing in a multi-nationality workforce: Examining the factors that influence knowledge sharing among employees of diverse nationalities. Human Systems Management, 34(3), 149-165.

Anantatmula, V. S. (2007). Linking KM effectiveness attributes to organizational performance. VINE: The Journal of Information and Knowledge Management Systems, 37(2), 133-149.

Ardichvili, A., Page, V., \& Wentling, T. (2003). Motivation and barriers to participation in virtual knowledgesharing communities of practice. Journal of Knowledge Management, 7(1), 64-77.

Bentler, P. M., \& Bonett, D. G. (1980). Significance tests and goodness of fit in the analysis of covariance structures. Psychological Bulletin, 88(3), 588.

Bock, G. W., Zmud, R. W., Kim, Y. G., \& Lee, J. N. (2005). Behavioral intention formation in knowledge sharing: Examining the roles of extrinsic motivators, social-psychological forces, and organizational climate. MIS Quarterly, 29(1), 87-111.

Bontis, N. \& Serenko, A. (2007). The moderating role of human capital management practices on employee capabilities. Journal of Knowledge Management, 11(3), 31-52.

Campbell, J. P. (1990). Modeling the performance prediction problem in industrial and organizational psychology. Handbook of Industrial and Organizational Psychology, 687-732.

Chaudhry, A. B. (2005). Knowledge sharing practices in Asian institutions: a multi-cultural perspective from Singapore. IFLA 2005.

Chiu, C. M., Hsu, M. H., \& Wang, E. T. (2006). Understanding knowledge sharing in virtual communities: An integration of social capital and social cognitive theories. Decision support systems, 42(3), 1872-1888.

Constant, D., Kiesler, S., \& Sproull, L. (1994). What's mine is ours, or is it? A study of attitudes about information sharing. Information Systems Research, 5(4), 400-421.

Davenport, T. H., \& Prusak, L. (1998). Working knowledge: How organizations manage what they know. Harvard Business Press.

Du, R., Ai, S., \& Ren, Y. (2007). Relationship between knowledge sharing and performance: A survey in Xi'an, China. Expert systems with Applications, 32(1), 38-46.

Hansen, S., \& Avital, M. (2005). Share and share alike: The social and technological influences on knowledge sharing behavior. Sprouts: Working Papers on Information Environments, Systems and Organizations, 5(1), $1-19$.

Ho, L. A., Kuo, T. H., \& Lin, B. (2012). How social identification and trust influence organizational online knowledge sharing. Internet Research, 22(1), 4-28.

Islam, S., Zeisel, A., Joost, S., La Manno, G., Zajac, P., Kasper, M., \& Linnarsson, S. (2014). Quantitative singlecell RNA-seq with unique molecular identifiers. Nature methods, 11(2), 163-166.

Kankanhalli, A., Tan, B. C., \& Wei, K. K. (2005). Contributing knowledge to electronic knowledge repositories: an empirical investigation. MIS quarterly, 29(1), 113-143.

Kanungo, R. N. (1982). Measurement of job and work involvement. Journal of Applied Psychology, 67(3), 341349.

Kuzu, Ö. H., \& Özilhan, D. (2014). The effect of employee relationships and knowledge sharing on employees' 
performance: An empirical research on service industry. Procedia-Social and Behavioral Sciences, 109, 1370-1374.

Lee, M. K., Cheung, C. M., Lim, K. H., \& Ling Sia, C. (2006). Understanding customer knowledge sharing in web-based discussion boards: An exploratory study. Internet Research, 16(3), 289-303.

Lee, H., \& Choi, B. (2003). Knowledge management enablers, processes, and organizational performance: An integrative view and empirical examination. Journal of Management Information Systems, 20(1), 179-228.

Liebowitz, J., \& Megbolugbe, I. (2003). A set of frameworks to aid the project manager in conceptualizing and implementing knowledge management initiatives. International Journal of Project Management, 21(3), 189198.

Lin, H. F. (2007). Knowledge sharing and firm innovation capability: an empirical study. International Journal of manpower, 28(3/4), 315-332.

Lin, H. F. (2007). Effects of extrinsic and intrinsic motivation on employee knowledge sharing intentions. Journal of Information Science, 33(2), 135-149.

Lodahl, T.M. \& Kejner, M. (1965). The development and measurement of job involvement. Journal of Applied Psychology, 49(1), 24-33.

Lu, L., Leung, K., \& Koch, P. T. (2006). Managerial knowledge sharing: The role of individual, interpersonal, and organizational factors. Management and Organization Review, 2(1), 15-41.

Mawoli, M. A., \& Babandako, A. Y. (2011). An evaluation of staff motivation, dissatisfaction and job performance in an academic setting. Australian Journal of Business and Management Research, 1(9), 1-13.

McAndrew, P., Clow, D., Taylor, J., \& Aczel, J. (2004). The evolutionary design of a knowledge network to support knowledge management and sharing for lifelong learning. British Journal of Educational Technology, 35(6), 739-746.

Mikulecky, P., \& Mikulecka, J. (1999). Active Tools for Better Knowledge Dissemination. Proceedings of the ASIS Annual Meeting, 36, 420-27.

Motowildo, S. J., Borman, W. C., \& Schmit, M. J. (1997). A theory of individual differences in task and contextual performance. Human Performance, 10(2), 71-83.

Muhammad, N., Rahman, B. A., Abd Rahman, W. Z., Idris, A. R., Sabri, S. M., \& Jusoff, K. (2011). Knowledge management practices (KMP) and academic performance in Universiti Teknologi Mara (UITM) Terengganu, Malaysia. World Applied Sciences Journal, 12(12), 21-26.

Nguyen, T. D., Nguyen, T. T., \& Barrett, N. J. (2008). Consumer ethnocentrism, cultural sensitivity, and intention to purchase local products-evidence from Vietnam. Journal of Consumer Behaviour: An International Research Review, 7(1), 88-100.

Nunnally, J. C., \& Bernstein, I. H. (1994). Psychometric Theory (McGraw-Hill Series in Psychology) (Vol. 3). New York: McGraw-Hill.

Oldenkamp, J. H. (2001). Limitations of managing knowledge sharing. In Proceedings of the Second European Conference on Knowledge Management, Bled, Slovenia, 411-418.

Onukwube, H.N., Iyabga, R. \& Fajana, S. (2010). The Influence of Motivation on Job performance of Construction Professionals in Construction Companies in Nigeria. Construction, Building and Real Australian Journal of Business and Management, 1(9), 2-6.

Osterloh, M., \& Frey, B. S. (2000). Motivation, knowledge transfer, and organizational forms. Organization Science, 11(5), 538-550.

Shin, S. K., Ishman, M., \& Sanders, G. L. (2007). An empirical investigation of socio-cultural factors of information sharing in China. Information \& Management, 44(2), 165-174.

Steenkamp, J.B., \& van Trijp, H. (1991). The use of LISREL in validating marketing constructs. International Journal of Research in Marketing, 8(4), 283-299.

Steiger, J. H. (1990). Structural model evaluation and modification: An interval estimation approach. Multivariate Behavioral Research, 25(2), 173-180.

Teece, D. J. (1998). Capturing value from knowledge assets: The new economy, markets for know-how, and intangible assets. California Management Review, 40(3), 55-79.

Teh, P. L., \& Sun, H. (2012). Knowledge sharing, job attitudes and organisational citizenship behaviour. Industrial Management \& Data Systems, 112(1), 64-82.

Tran, T.P.A., Doan, Q.M., Cao, T.P., Nguyen, V.T. (2013). Knowledge sharing \& Acquisition in organizations: an empirical study in the public as well as private sectors in Vietnam. Proceeding of $9^{\text {th }}$ international conference on humanities and social sciences, Khon Kaen University - Thailand, 1900-1913.

Van Den Hooff, B. \& De Ridder, J.A. (2004). Knowledge sharing in context: the influence of organizational commitment, communication climate and CMC usage on knowledge sharing. Journal of Knowledge 
Management, 8(6), 117-30.

Van den Hooff, B., \& de Leeuw van Weenen, F. (2004). Committed to share: commitment and CMC use as antecedents of knowledge sharing. Knowledge and Process Management, 11(1), 13-24.

Von Krogh, G., Ichijo, K., \& Nonaka, I. (2000). Enabling knowledge creation: How to unlock the mystery of tacit knowledge and release the power of innovation. Oxford university press.

Wasko, M. M., \& Faraj, S. (2005). Why should I share? Examining social capital and knowledge contribution in electronic networks of practice. MIS Quarterly, 29(1), 35-57.

Weggeman, M. (2000). Kennismanagement: de Praktijk [Knowledge Management: Practice]. Schiedam: Scriptum Management.

Zakaria, N., Amelinckx, A., \& Wilemon, D. (2004). Working together apart? Building a knowledge-sharing culture for global virtual teams. Creativity and Innovation Management, 13(1), 15-29.

Zhao, H., \& Luo, Y. (2005). Antecedents of knowledge sharing with peer subsidiaries in other countries: A perspective from subsidiary managers in a foreign emerging market. MIR: Management International Review, 45(1), 71-97.

\section{Appendix 1}

\begin{tabular}{|c|c|c|}
\hline Factors & $\begin{array}{c}\text { Sym } \\
\text { bol }\end{array}$ & Items \\
\hline \multirow{4}{*}{$\begin{array}{l}\text { Enjoyment in } \\
\text { helping others } \\
\text { (En) }\end{array}$} & En1 & I enjoy sharing my knowledge with colleagues \\
\hline & En2 & I enjoy helping colleagues by sharing my knowledge \\
\hline & En3 & It feels good to help someone by sharing my knowledge \\
\hline & En4 & Sharing my knowledge with colleagues is pleasurable \\
\hline \multirow{5}{*}{$\begin{array}{l}\text { Knowledge self- } \\
\text { efficacy (Se) }\end{array}$} & Se1 & My knowledge sharing would help other numbers in the organization to solve their problems \\
\hline & $\mathrm{Se} 2$ & My knowledge sharing would create new business opportunities for the organization \\
\hline & $\mathrm{Se} 3$ & My knowledge sharing would improve work process in the organization \\
\hline & $\mathrm{Se} 4$ & My knowledge sharing would increase productively in the organization \\
\hline & Se5 & My knowledge sharing would help the organization achieve its performance objectives \\
\hline \multirow{5}{*}{$\begin{array}{l}\text { Job involvement } \\
\text { (In) }\end{array}$} & In1 & The most important things that happen to me involve my present job \\
\hline & In2 & Most of my interests are centered around my job \\
\hline & In3 & I have very strong ties with my present job which would be very difficult to break \\
\hline & In4 & I like to be absorbed in my job most of the time \\
\hline & In5 & The most important things that happen in life involve work \\
\hline \multirow{5}{*}{$\begin{array}{l}\text { Management } \\
\text { support } \\
\text { (Ma) }\end{array}$} & Ma1 & My manager always set a good example in sharing his knowledge with others \\
\hline & Ma2 & My manager supports me in sharing knowledge with colleagues in other departments \\
\hline & Ma3 & My manager allows me to share my knowledge with my colleagues even though it may influence the present job process \\
\hline & Ma4 & My manager instructs us on how to share our personal knowledge within the department \\
\hline & Ma5 & My manager does not care about my knowledge and does not encourage me to share my knowledge with other colleagues \\
\hline \multirow{4}{*}{ Rewards (Re) } & Re1 & Sharing my knowledge with colleagues should be rewarded with a higher salary \\
\hline & Re2 & Sharing my knowledge with colleagues should be rewarded with a higher bonus \\
\hline & $\operatorname{Re} 3$ & Sharing my knowledge with colleagues should be rewarded with a promotion \\
\hline & Re4 & Sharing my knowledge with colleagues should be rewarded with an increased job security \\
\hline \multirow{3}{*}{$\begin{array}{l}\text { Information and } \\
\text { communication } \\
\text { technology }(\mathrm{Te})\end{array}$} & Te1 & Work related information and knowledge are stored, classified and updated in a scientific and regular manner \\
\hline & $\mathrm{Te} 2$ & The organization's IT system provides valuable and useful information/data for my work \\
\hline & Te3 & The organization's IT system facilitates the sharing of knowledge and information among members \\
\hline \multirow{4}{*}{$\begin{array}{l}\text { Knowledge } \\
\text { donation } \\
\text { (Do) }\end{array}$} & Do1 & When I learn something new, I tell my colleagues about it \\
\hline & Do2 & I share the knowledge I have, with my colleagues \\
\hline & Do3 & I think it is important that my colleagues know what I am doing \\
\hline & Do4 & I regularly tell my colleagues what I am doing \\
\hline \multirow{4}{*}{$\begin{array}{l}\text { Knowledge } \\
\text { collection (Co) }\end{array}$} & Co1 & When I need certain knowledge, I ask my colleagues about it \\
\hline & $\mathrm{Co} 2$ & I like to be informed of what my colleagues know \\
\hline & $\mathrm{Co3}$ & I ask my colleagues about their abilities when I need to learn something \\
\hline & $\mathrm{Co} 4$ & When one of my colleagues is good at something I ask him/her to teach me how to do that thing \\
\hline \multirow{9}{*}{$\begin{array}{l}\text { Individual } \\
\text { performance }(\mathrm{Pe})\end{array}$} & Pel & I completed more work than the expectations of the manager \\
\hline & $\mathrm{Pe} 2$ & I can finish all the work earlier than the assigned plan \\
\hline & $\mathrm{Pe} 3$ & I can reduce the time required to complete my daily work \\
\hline & $\mathrm{Pe} 4$ & The results of my work always exceed the work goals assigned by managers \\
\hline & Pe5 & I have ideas and useful suggestions for the university \\
\hline & Pe6 & I always meet the wishes of learners \\
\hline & Pe7 & I have never had any delays in my work or caused anything to do with my carelessness \\
\hline & Pe8 & I have never received any complaints about poor performance \\
\hline & Pe9 & The manager is always satisfied with my results \\
\hline
\end{tabular}


Appendix 2

\begin{tabular}{|c|c|c|c|}
\hline Factor & Item & Factor loading & Cronbach's Alpha \\
\hline \multirow{4}{*}{ Enjoyment in helping others } & En1 & 0.870 & \multirow{4}{*}{0.884} \\
\hline & En2 & 0.871 & \\
\hline & En3 & 0.762 & \\
\hline & En4 & 0.799 & \\
\hline \multirow{3}{*}{ Knowledge self-efficacy } & $\mathrm{Se} 3$ & 0.702 & \multirow{3}{*}{0.860} \\
\hline & $\mathrm{Se} 4$ & 0.702 & \\
\hline & $\mathrm{Se} 5$ & 0.925 & \\
\hline \multirow{3}{*}{ Job involvement } & $\operatorname{In} 2$ & 0.810 & \multirow{3}{*}{0.707} \\
\hline & In4 & 0.709 & \\
\hline & In5 & 0.597 & \\
\hline \multirow{5}{*}{ Management support } & Mal & 0.862 & \multirow{5}{*}{0.846} \\
\hline & $\mathrm{Ma} 2$ & 0.862 & \\
\hline & Ma3 & 0.589 & \\
\hline & Ma4 & 0.817 & \\
\hline & Ma5 & 0.654 & \\
\hline \multirow{4}{*}{ Rewards } & Rel & 0.910 & \multirow{4}{*}{0.907} \\
\hline & $\operatorname{Re} 2$ & 0.897 & \\
\hline & $\operatorname{Re} 3$ & 0.854 & \\
\hline & Re4 & 0.738 & \\
\hline \multirow{3}{*}{ Information and communication technology } & Te1 & 0.650 & \multirow{3}{*}{0.799} \\
\hline & Te2 & 0.792 & \\
\hline & Te3 & 0,791 & \\
\hline \multirow{4}{*}{ Knowledge donation } & Do1 & 0.571 & \multirow{4}{*}{0.779} \\
\hline & Do2 & 0.531 & \\
\hline & Do3 & 0.638 & \\
\hline & Do4 & 0.674 & \\
\hline \multirow{4}{*}{ Knowledge collection } & Col & 0.701 & \multirow{4}{*}{0.766} \\
\hline & $\mathrm{Co} 2$ & 0.712 & \\
\hline & Co3 & 0.745 & \\
\hline & $\mathrm{Co} 4$ & 0.698 & \\
\hline \multirow{8}{*}{ Individual performance } & Pe1 & 0.611 & \multirow{8}{*}{0.801} \\
\hline & $\mathrm{Pe} 2$ & 0.607 & \\
\hline & $\mathrm{Pe} 3$ & 0.631 & \\
\hline & $\mathrm{Pe} 4$ & 0.666 & \\
\hline & Pe6 & 0.574 & \\
\hline & $\mathrm{Pe} 7$ & 0.808 & \\
\hline & Pe8 & 0.853 & \\
\hline & Pe9 & 0.793 & \\
\hline
\end{tabular}

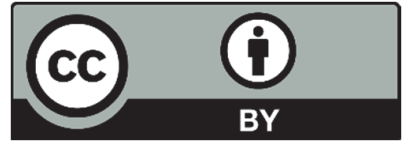

(C) 2019 by the authors; licensee Growing Science, Canada. This is an open access article distributed under the terms and conditions of the Creative Commons Attribution (CC-BY) license (http://creativecommons.org/licenses/by/4.0/). 